Article

\title{
Biological Treatment of Wastewater from Pyrolysis Plant: Effect of Organics Concentration, pH and Temperature
}

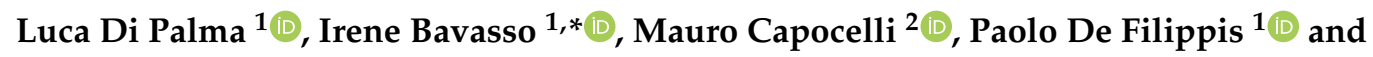 \\ Vincenzo Piemonte ${ }^{2}$ \\ 1 Department of Chemical Engineering Materials \& Environment, Sapienza University of Rome, \\ Via Eudossiana, 18, 00184 Rome, Italy; luca.dipalma@uniroma1.it (L.D.P.); \\ paolo.defilippis@uniroma1.it (P.D.F.) \\ 2 Faculty of Engineering, University Campus Biomedico of Rome, Via Alvaro del Portillo, 21, \\ 00128 Rome, Italy; m.capocelli@unicampus.it (M.C.); V.Piemonte@unicampus.it (V.P.) \\ * Correspondence: irene.bavasso@uniroma1.it
}

Received: 19 December 2018; Accepted: 12 February 2019; Published: 16 February 2019

\begin{abstract}
The biological treatment of the aqueous residue produced during poplar wood pyrolysis was investigated. The biological treatment experiments were carried out at two different $\mathrm{pH}$ conditions (controlled at 7 , uncontrolled) in batch mode at three different temperatures $\left(15{ }^{\circ} \mathrm{C}\right.$, $25^{\circ} \mathrm{C}$ and $30^{\circ} \mathrm{C}$ ) and initial total organic carbon of the water ranging from $800 \mathrm{mg} / \mathrm{L}$ to $2800 \mathrm{mg} / \mathrm{L}$. Results show that a substantial removal of organic carbon could be achieved in aerobic conditions after biomass acclimation. After $72 \mathrm{~h}$ of treatment, total organic carbon (TOC) removal mean values of $49.47 \%$ and $53.03 \%$ were observed at $30{ }^{\circ} \mathrm{C}$ for solution at 1400 and $2000 \mathrm{mg} / \mathrm{L}$ initial TOC, respectively. In the case of $1400 \mathrm{mg} / \mathrm{L}$, a further mineralization $(61.80 \%)$ was achieved during $144 \mathrm{~h}$ of treatment, by using a two-step process. A kinetic study of the process was also made, showing that organics mineralization followed a first-order kinetic model.
\end{abstract}

Keywords: pyrolysis; liquid residue; biological treatment; operative conditions; kinetics

\section{Introduction}

Pyrolysis is the thermal decomposition of organic matrices in the absence of oxidizing agents, with the production of an array of solids, liquid and gaseous products [1]. The interest in pyrolysis is mainly related to the conversion of solid biomass and organic wastes into liquid products (bio-oil and water containing soluble organics compounds), thus showing great advantages in terms of transport and storage [2]. Seeking to achieve an environmentally sound production based on the principles of circular economy, pyrolysis bio-oil can be successfully used to replace fossil fuel for heat and power generation, providing a renewable source of energy. In addition, the solid residue (char) could be used as cheap carbon-based material precursor for the production of activated carbon [3-5], the properties of which depend on the raw materials and activation processes used [6,7]. The liquid generated during the pyrolysis process, also known as "pyroligneous liquor" is a complex mixture of water, alcohols, organic acids, phenols, aldehydes, ketones, esters, furan and pyran derivatives, hydrocarbons, and nitrogen compounds [8,9], yield and composition depending on the operating conditions of the process as well as biomass composition.

While the process is highly variable, it typically produces an amount of highly polluted wastewater that accounts for up to $50 \%$ of the liquid phase.

Many organic compounds and a list of hazardous constituents have been identified in such wastewaters [10]. As an example, the reddish-brown wood distillate was considered in the past as 
a major source of chemicals, including acetic acid and methanol. At present the recovery of chemicals appears to not be economically feasible, especially in the case of small decentralized plants, although it still has some minor application as natural antiseptic, and in the food industry as additives [11], and smoke flavoring [12]. The correct disposal of pyrolysis aqueous phase becomes, therefore, critical for the diffusion of small-scale pyrolysis technology; as a consequence alternative treatment technologies need to be evaluated to limit the environmental impact of such products [13].

To this purpose, physicochemical methods, mainly based on radical mechanisms activated through the combined use of ozone, $\mathrm{H}_{2} \mathrm{O}_{2}, \mathrm{UV}$, cavitation (Advanced Oxidation Processes-AOP), have been proposed for the destruction of refractory organic pollutants [14,15]. Catalytic and photocatalytic ozonation of pyrolysis wastewaters showed good results in alkaline conditions [16].

As an alternative, chemical processes could be used to increase wastewater biodegradability as a pretreatment of a biological process. Silva et al. [17] reported promising results of the hybrid electrochemical/microbiological degradation of phenolic compounds from pyrolysis wastewater. Despite these methods having demonstrated high treatment efficiencies, they still present a relative high-energy footprint and can generate uncontrolled by-products [18]. Therefore, these methods are still considered complex and expensive with respect to the most common biological oxidation processes, which are generally environmentally friendly and cost-effective $[19,20]$.

Furthermore, the biological oxidation of selected pollutants generally found in pyrolysis wastewater have already been investigated, even in complex mixtures [21].

To our knowledge, very few experiments of biological treatment of pyrolysis wastewater have been carried out. In addition, biodegradation efficiency is strongly related to the biomass pyrolyzed due to the presence of slowly biodegradable or even refractory compounds.

In this paper, the aerobic biological process has been investigated as a possible solution for the treatment of pyrolysis wastewater. A careful investigation of the influence of operating conditions was performed, by evaluating the effect of total organic carbon (TOC) concentration, $\mathrm{pH}$ conditions and temperature on biodegradation efficiency. A simplified kinetic model has also been proposed to evaluate the experimental results.

\section{Materials and Methods}

\subsection{Pyrolysis Process}

Pyrolysis of dried and crushed poplar wood was carried out in a continuous screw reactor ( $25 \mathrm{~mm}$ i.d., $550 \mathrm{~mm}$ length) under $\mathrm{N}_{2}$ atmosphere. Before starting the pyrolysis experiment, $150 \mathrm{~g}$ of dried biomass was loaded in the hopper, and the system was flushed with nitrogen at $500 \mathrm{~mL} / \mathrm{min}$ to ensure inert atmosphere. After $30 \mathrm{~min}$, the reactor was heated up to $450{ }^{\circ} \mathrm{C}$ and the feeding was started at a rate of $100 \mathrm{~g} / \mathrm{h}$. The vapors produced during biomass pyrolysis were cooled down and the condensate collected in liquid traps. The condensate separates spontaneously into two phases, an organic phase, the so called bio-oil, and an aqueous phase. In this work, to reduce the separation time and to assure a reduced amount of bio drops in the aqueous phase, a centrifugation step was also adopted. The aqueous phase was then analyzed by a GC-MS analyzer (Agilent, Santa Clara, CA, USA) using a thin film ( $30 \mathrm{~m} \times 0.32 \mathrm{~mm}, 0.5 \mu \mathrm{m}$ film thickness) HP-MS5 capillary column to determine the main soluble organic compounds TOC and $\mathrm{pH}$ were also determined. The main characteristics of the aqueous phase are reported in Table 1. 
Table 1. Main physicochemical characteristic of the aqueous phase.

\begin{tabular}{|c|c|c|}
\hline Parameter & \multicolumn{2}{|l|}{ Value } \\
\hline TOC & \multicolumn{2}{|l|}{$82,700 \mathrm{mg} / \mathrm{L}$} \\
\hline $\mathrm{pH}$ & \multicolumn{2}{|l|}{3.2} \\
\hline \multicolumn{3}{|c|}{ List of the soluble organic compounds on dry basis } \\
\hline Retention Time (min) & Organic Compound & Mass Fraction $(\%)$ \\
\hline 1.85 & Acetic acid, methyl ester & 8.65 \\
\hline 1.97 & Acetic acid & 24.49 \\
\hline 1.98 & 2-Butanol & 11.92 \\
\hline 2.22 & 2-Propanone, 1-hydroxy- & 12.48 \\
\hline 2.30 & Propanoic acid & 4.36 \\
\hline 2.42 & 2-Butanone, 3-hydroxy- & 3.64 \\
\hline 2.61 & 2-Butanol, 3-methyl- & 0.72 \\
\hline 2.70 & Butanamide, 3,N-dihydroxy- & 0.44 \\
\hline 2.79 & 1-Hydroxy-2-butanone & 2.63 \\
\hline 2.84 & Butanoic acid & 0.78 \\
\hline 2.89 & Propanal & 2.02 \\
\hline 2.99 & Cyclopentanone & 1.36 \\
\hline 3.05 & 3-Pentanol & 0.84 \\
\hline 3.11 & Butane,2-ethoxy- & 0.64 \\
\hline 3.36 & 2-Cyclopenten-1-one & 3.86 \\
\hline 3.55 & Pentane, 1,3-epoxy-4-methyl- & 0.65 \\
\hline 3.87 & 2-Furanmethanol, tetrahydro- & 0.26 \\
\hline 3.90 & 1,3-Butanediol & 0.62 \\
\hline 4.05 & 2-Cyclopenten-1-one, 2-methyl- & 1.37 \\
\hline 4.09 & Ethanone, 1-(2-furanyl)- & 0.50 \\
\hline 4.12 & Butyrolactone & 3.74 \\
\hline 4.52 & $\begin{array}{l}\text { 2(3H)-Furanone, } \\
\text { dihydro-5-methyl- }\end{array}$ & 0.62 \\
\hline 4.57 & 2H-Pyran-2-one, tetrahydro- & 0.43 \\
\hline 4.65 & 2-Cyclopenten-1-one, 3-methyl- & 1.06 \\
\hline 4.81 & Phenol & 1.15 \\
\hline 4.94 & 6-Methyl-3-heptyne & 0.30 \\
\hline 4.98 & Cyclohexanone, 3-methyl-, (R)- & 0.29 \\
\hline 5.00 & 1-Hydroxy-2-pentanone & 0.56 \\
\hline 5.23 & 1,2-Cyclopentanedione, 3-methyl- & 3.10 \\
\hline 5.35 & 2-Cyclopenten-1-one, 2,3-dimethyl & 0.52 \\
\hline 5.48 & 2-Hydroxy-3,5-dimethylcyclopent-2-en-1-one & 1.25 \\
\hline 5.80 & Phenol, 2-methoxy- & 2.46 \\
\hline 6.07 & $\begin{array}{l}\text { 2-Cyclopenten-1-one, } \\
\text { 3-ethyl-2-hydroxy }\end{array}$ & 0.50 \\
\hline 6.30 & 4-Isoprpylcyclohexanone & 0.51 \\
\hline 6.74 & Phenol, 2-methoxy-4-methyl- & 1.11 \\
\hline
\end{tabular}

\subsection{Biological Treatment of the Liquid Residue}

A microbial biomass from municipal wastewater treatment was used. Microbial acclimation was carried out in a $1 \mathrm{~L}$ glass batch reactor, filled by $800 \mathrm{~mL}$ of municipal wastewater, by addition of $20 \mathrm{~mL}$ of pyrolysis wastewater every 5 days for a month, at $25{ }^{\circ} \mathrm{C}$ under aerated condition and stirring at $1000 \mathrm{rpm}$ by Velp Scientifica (Velp Scientifica, Usmate, Italy) magnetic stirrer.

The biomass taken from the acclimation reactor $(5 \mathrm{~mL})$ was inoculated in $500 \mathrm{~mL}$ flasks, where batch tests were conducted to investigate the effect of TOC, $\mathrm{pH}$ and temperature on the biodegradation rate. In the first series of tests performed at $30{ }^{\circ} \mathrm{C}$, the effect of initial organics concentration was investigated. To this aim, TOC starting values of $800 \mathrm{mg} / \mathrm{L}, 1400 \mathrm{mg} / \mathrm{L}, 2000 \mathrm{mg} / \mathrm{L}$ and $2800 \mathrm{mg} / \mathrm{L}$ were tested. 
Subsequently the effect temperature was assessed through tests at $15{ }^{\circ} \mathrm{C}, 25^{\circ} \mathrm{C}$ and $30^{\circ} \mathrm{C}$ and fixed $\mathrm{pH}$ conditions $(\mathrm{pH}=7)$ obtained by adding to the reactor an equimolar buffer phosphate solution to the reactor, and at an initial TOC concentration of $1400 \mathrm{mg} / \mathrm{L}$. The tests lasted $72 \mathrm{~h}$ and were carried out under oxygen flow $(3.5 \mathrm{~L} / \mathrm{min}$ ) provided by an air pump (AC 9902, Resun, Shenzhen, China).

A supplementary test was finally performed by adding a second reactor in series, to evaluate the enhancement of the degradation rate by the addition of acclimated microbial biomass.

Samples from each reactor were analyzed in term of TOC (Total Organic Carbon analyzer TOC-L, Shimadzu, Milan, Italy), and pH (GLP21, Crison Instrument, Barcelona, Spain). Chemical oxygen demand (COD) was measured by the colorimetric method [22] with an UV/Vis spectrophotometer (UV-2700, Shimadzu Co., Kyoto, Japan).

All results are reported as mean value of at least three repetitions and a standard deviation of $5 \%$ was calculated.

\section{Results}

\subsection{Influence of the Initial Concentration}

Figure 1 reports trend of TOC removal during the $72 \mathrm{~h}$ aerobic degradation experiments for water at different initial TOC values.

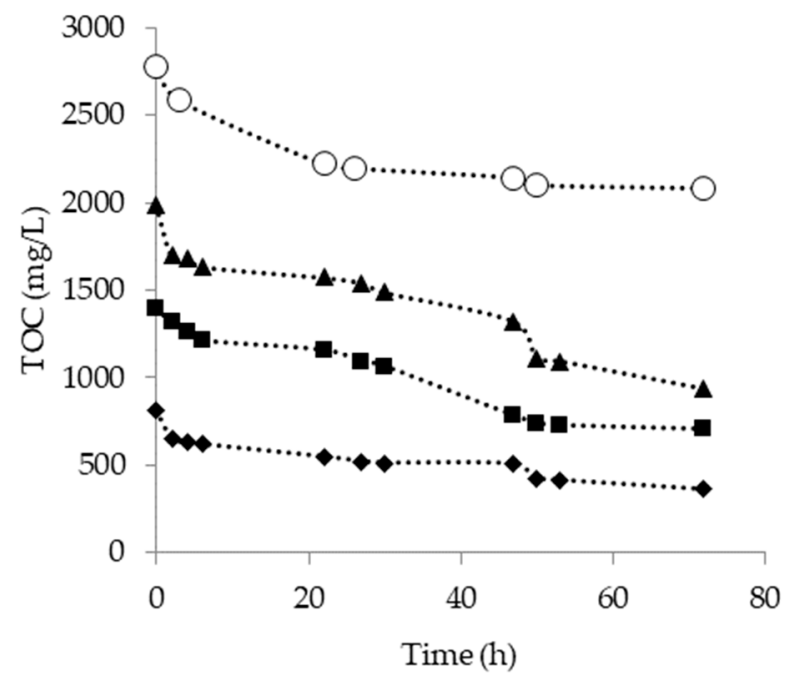

Figure 1. Total organic carbon (TOC) removal trends during the aerobic treatment of pyrolysis wastewater at $30{ }^{\circ} \mathrm{C}$ (TOC initial concentration: (\$) $800 \mathrm{mg} / \mathrm{L},(\boldsymbol{\square}) 1400 \mathrm{mg} / \mathrm{L},(\boldsymbol{\Delta}) 2000 \mathrm{mg} / \mathrm{L}$ and (○) $2800 \mathrm{mg} / \mathrm{L})$.

During $72 \mathrm{~h}$ of biodegradation at $30^{\circ} \mathrm{C}$ and uncontrolled $\mathrm{pH}$, TOC removal efficiency was similar for all the tested initial TOC concentration up to $2000 \mathrm{mg} / \mathrm{L}$. Removal of TOC was $55.65 \%, 49.47 \%$ and $53.03 \%$ for initial TOC $800 \mathrm{mg} / \mathrm{L}, 1400 \mathrm{mg} / \mathrm{L}$, and $2000 \mathrm{mg} / \mathrm{L}$, respectively. These results suggested that microorganism acclimation successfully occurred. The TOC removal rate for the initial concentrations of TOC $800 \mathrm{mg} / \mathrm{L}, 1400 \mathrm{mg} / \mathrm{L}$, and $2000 \mathrm{mg} / \mathrm{L}$ for $72 \mathrm{~h}$, shows a similar trend, and the TOC profile show an alternating degradation period and adaptation period (Figure 1).

The same microbial activity is shown in the COD degradation (Figure 2). In fact COD/TOC ratio in experiments with an initial TOC concentration $800 \mathrm{mg} / \mathrm{L}, 1400 \mathrm{mg} / \mathrm{L}$, and $2000 \mathrm{mg} / \mathrm{L}$ was almost constant, and equal to $2.44( \pm 0.29), 2.72( \pm 0.14)$, and $2.78( \pm 0.19)$, respectively. Such proportional removal of COD and TOC also highlighted the absence of other reducing compounds apart from organic compounds in the tested pyrolysis wastewater. 


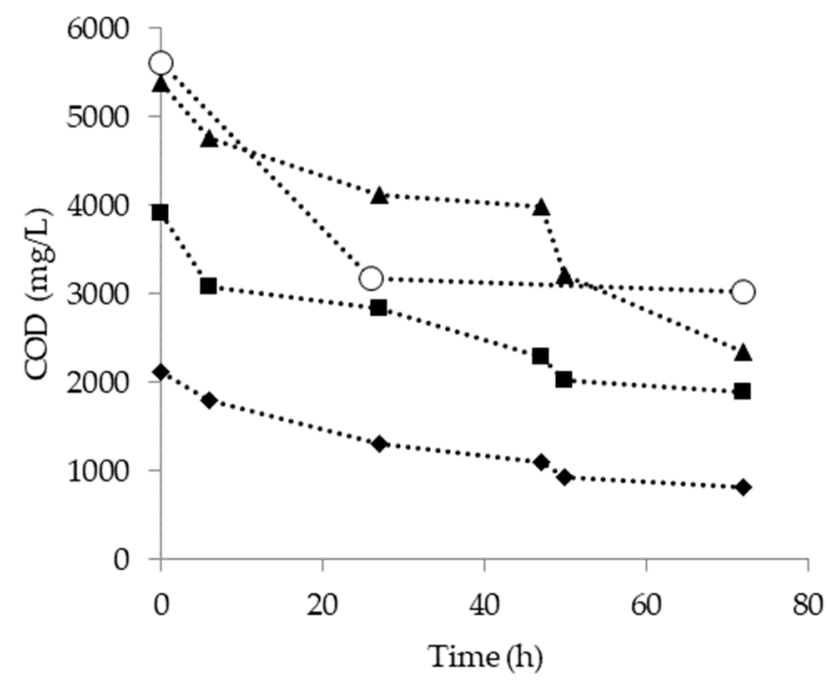

Figure 2. Chemical oxygen demand (COD) removal trends during the aerobic treatment of pyrolysis wastewater at $30{ }^{\circ} \mathrm{C}$ (TOC initial concentration: $(\diamond) 800 \mathrm{mg} / \mathrm{L},(\mathbf{\square}) 1400 \mathrm{mg} / \mathrm{L},(\boldsymbol{\Delta}) 2000 \mathrm{mg} / \mathrm{L}$ and (○) $2800 \mathrm{mg} / \mathrm{L})$.

By comparing the TOC and COD degradation curves (Figures 1 and 2), the highest TOC and COD removal rate $(21.02 \%$ and $43.21 \%)$ was observed during the first $24 \mathrm{~h}$ of degradation at the initial TOC $2800 \mathrm{mg} / \mathrm{L}$, but further degradation was negligible. In this case, the largest proportion of readily and hardly biodegradable compounds was observed and this could be explained by the occurrence of an initial fast degradation followed by inhibition of the microbial biomass. Ruiz-Ordaz and co-workers (1998) found that a concentration of phenols, as an organic carbon source exceeding $2500 \mathrm{mg} / \mathrm{L}$ (TOC $1900 \mathrm{mg} / \mathrm{L}$ ) determined a substrate inhibition due to their toxicity effect on microbial growth [23]. In the present work, the overall concentration of phenolic compounds resulted in a TOC value of $140 \mathrm{mg} / \mathrm{L}$, suggesting that the inhibitory effect cannot be associated only with phenolic compounds but also with the co-presence of slowly biodegradable or even refractory species such as butyrolactone (3.47\%) [24]. However, since acetic acid was the most abundant fraction of the liquid phase, the occurrence of $\mathrm{pH}$ fluctuations in the reaction media was assumed to be the main factor responsible for the inhibition of microorganisms activity [25].

Acidic conditions were observed during the $72 \mathrm{~h}$ of treatment in all the tests, except at the low TOC initial value $(800 \mathrm{mg} / \mathrm{L}$ ), where neutral condition ( $\mathrm{pH}$ equal to 7.2$)$ were achieved after $27 \mathrm{~h}$ (Figure 3). This result suggests that in the case of low TOC values a faster degradation occurred, with the mineralization of acidic compounds, thus resulting in a quick increase of $\mathrm{pH}$. On the basis of the above results and in view of the implementation of a biological step for the treatment of pyrolysis wastewater, a pretreatment depending upon organics concentration could be required to reduce initial organics concentration to a suitable range for bacterial degradation. To this aim an additional test of bioaugmentation was carried out: $1400 \mathrm{mg} / \mathrm{L}$ was considered as optimal value for the biological treatment of pyrolysis water. After the first $72 \mathrm{~h}$ treatment a new amount of biomass $(5 \mathrm{~mL})$ was added by driving the test for further $72 \mathrm{~h}$. A further degradation (from 72-144 h) was interpreted from the initial TOC $1400 \mathrm{mg} / \mathrm{L}$ at $30^{\circ} \mathrm{C}$, and resulted in a degradation of TOC of $61.80 \%$, after $144 \mathrm{~h}$ (Figure 4). 


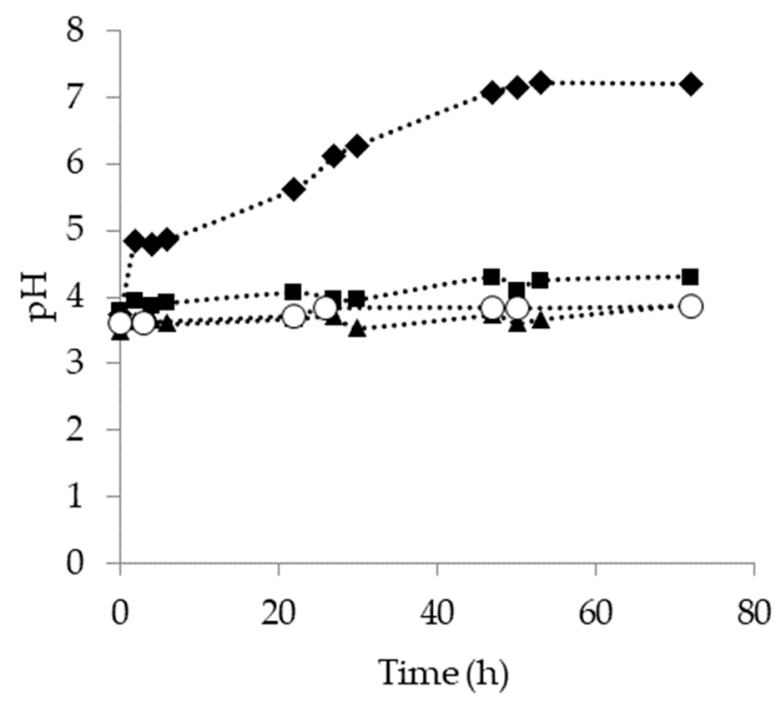

Figure 3. $\mathrm{pH}$ evolution during the aerobic treatment of pyrolysis wastewater at $30{ }^{\circ} \mathrm{C}$ (TOC initial concentration: $(\diamond) 800 \mathrm{mg} / \mathrm{L},(\mathbf{\square}) 1400 \mathrm{mg} / \mathrm{L},(\boldsymbol{\Delta}) 2000 \mathrm{mg} / \mathrm{L}$ and $(\bigcirc) 2800 \mathrm{mg} / \mathrm{L})$.

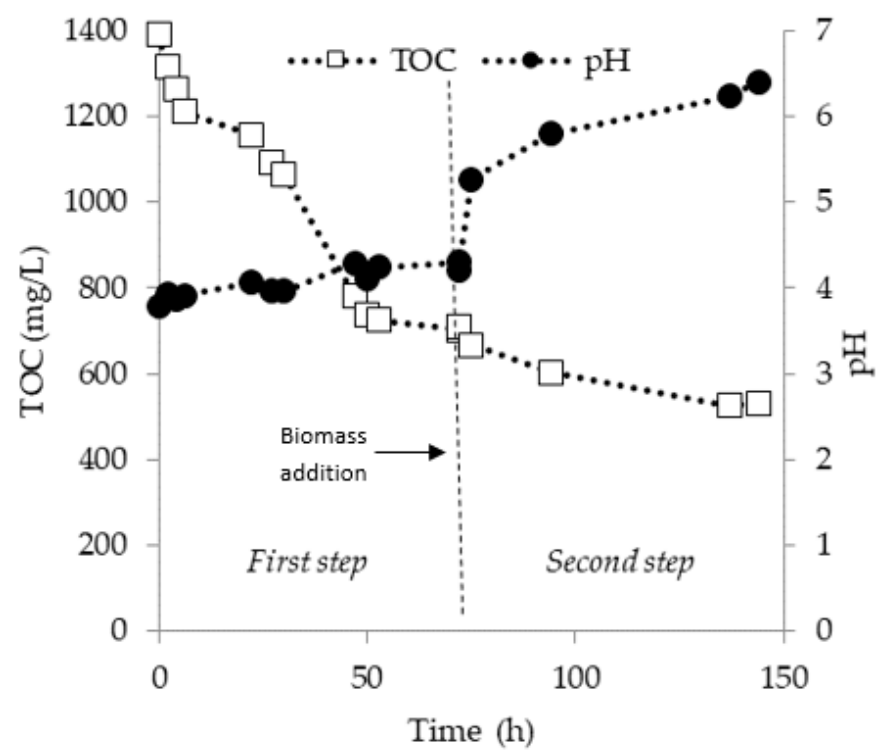

Figure 4. Aerobic biological with two-reactor system of pyrolysis wastewater with TOC initial value equal to $1400 \mathrm{mg} / \mathrm{L}$ at $30{ }^{\circ} \mathrm{C}$.

A reduction of COD/TOC down to 1.77 after $144 \mathrm{~h}$ was determined.

\subsection{Influence of $p H$}

Tests were carried out to investigate the effect of $\mathrm{pH}$ on organic degradation at an initial concentration of $1400 \mathrm{mg} / \mathrm{L}$. In Figure 5, TOC and COD removal over time are presented in the tests performed at controlled $(\mathrm{pH}=7)$ and uncontrolled $\mathrm{pH}$. 


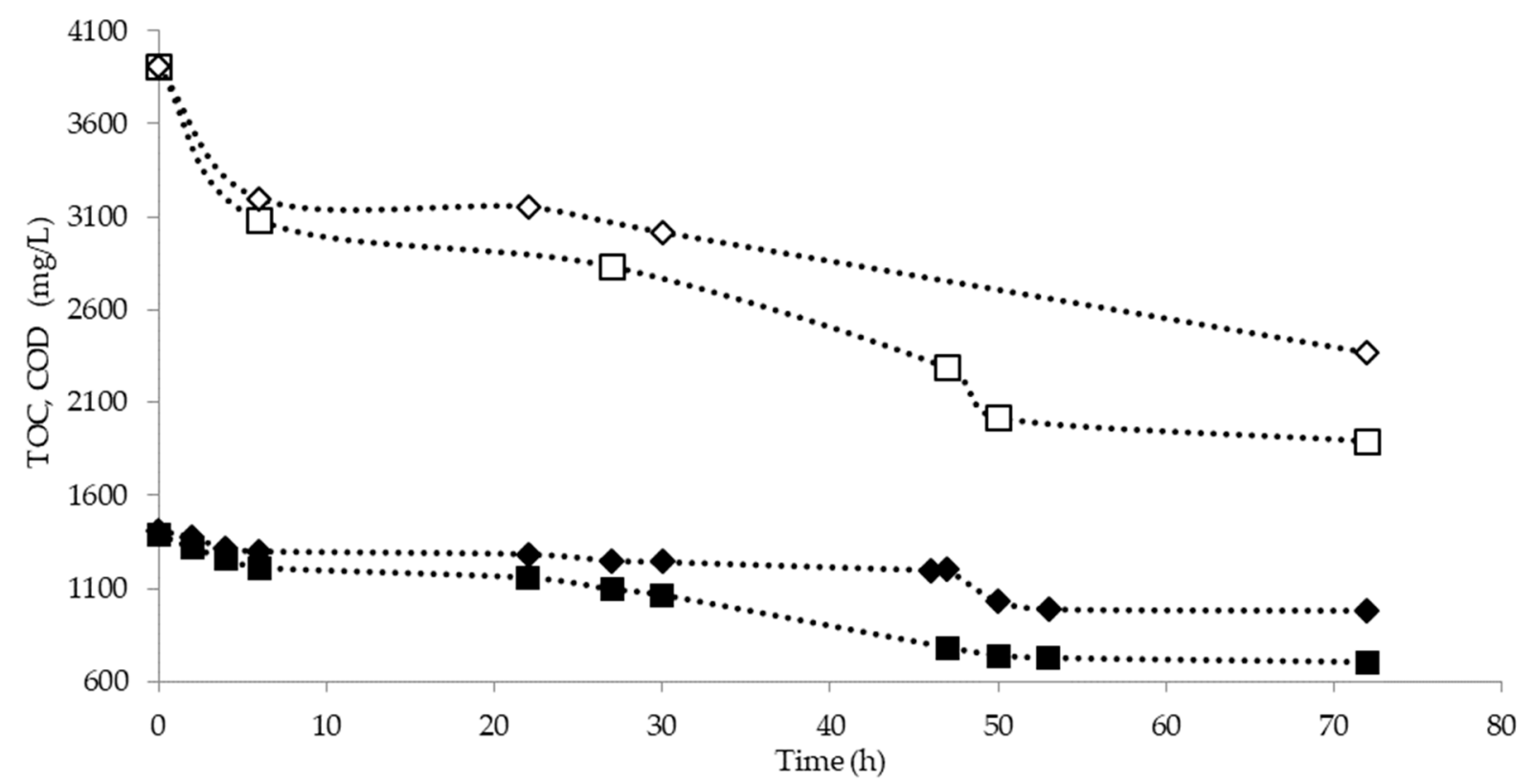

Figure 5. Effect of $\mathrm{pH}$ on aerobic biological treatment of pyrolysis wastewater. COD (empty symbols) and TOC (full symbols) at free $\mathrm{pH}$ (square) and $\mathrm{pH}=7$ (rhomboid).

In the tests performed at $\mathrm{pH}=7$, a $30.12 \%$ TOC removal and $39.40 \%$ COD removal were observed. Comparing these values to the corresponding values obtained in the tests performed at uncontrolled $\mathrm{pH}(49.47 \%$ TOC removal and $51.54 \%$ COD removal), it was possible to confirm that neutral $\mathrm{pH}$ compromised the microbial metabolism reducing process effectiveness (Figure 5). This effect also suggests that the acclimation of microorganism under acidic $\mathrm{pH}$ conditions could result in a process enhancement and prevent process inhibition under acidic conditions [26,27].

\subsection{Influence of Temperature}

In regards to the influence of temperature on the degradation rate, tests at $15^{\circ} \mathrm{C}, 25^{\circ} \mathrm{C}$ and $30{ }^{\circ} \mathrm{C}$ were performed at $1400 \mathrm{mg} / \mathrm{L}$, initial TOC value and at uncontrolled $\mathrm{pH}$. The results of TOC and COD removal yields are reported in Figure 6.

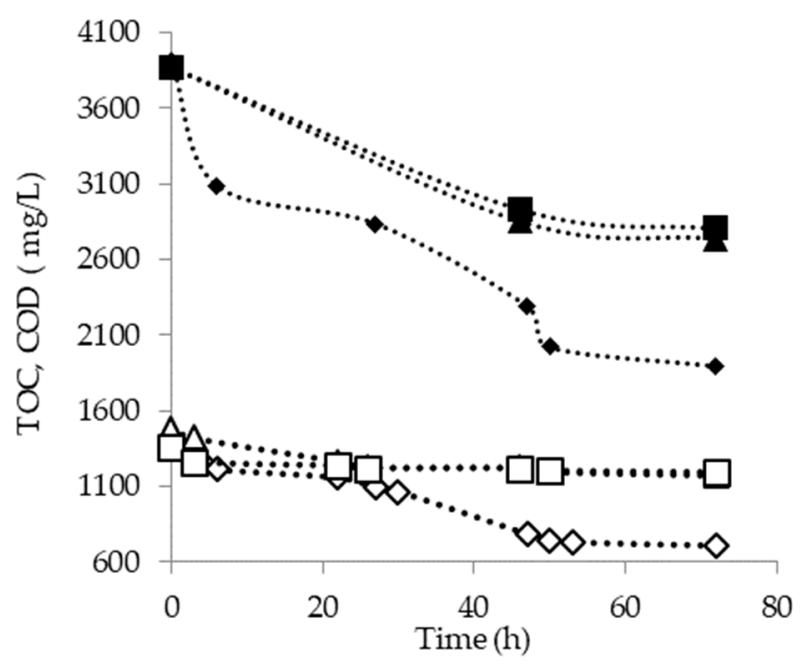

Figure 6. Effect of temperature on aerobic biological treatment of pyrolysis wastewater. COD (full symbols) and TOC (empty symbols) at $15^{\circ} \mathrm{C}$ (triangle), $25^{\circ} \mathrm{C}$ (square) and $30^{\circ} \mathrm{C}$ (rhomboid). 
As expected, the TOC and COD removal rate increased when temperature increased. TOC removal was $12.62 \%, 20.90 \%$ and $49.47 \%$ for tests performed at $15{ }^{\circ} \mathrm{C}, 25^{\circ} \mathrm{C}$ and $30^{\circ} \mathrm{C}$, respectively, while the COD removal in the same tests was $27.47 \%, 29.35 \%$ and $51.54 \%$. The mean COD/TOC ratio values after $72 \mathrm{~h}$ of treatment in these last tests were $2.54( \pm 0.27), 2.64( \pm 0.17)$ and $2.72( \pm 0.14)$ respectively, in accordance with the results discussed above. The results confirm the inhibiting effect of low temperature on microorganisms activity, as generally observed in the aerobic oxidation process [25]. $\mathrm{pH}$ values measured in these tests, are reported in Figure 7. Results show that acidic conditions were established during the experiments.

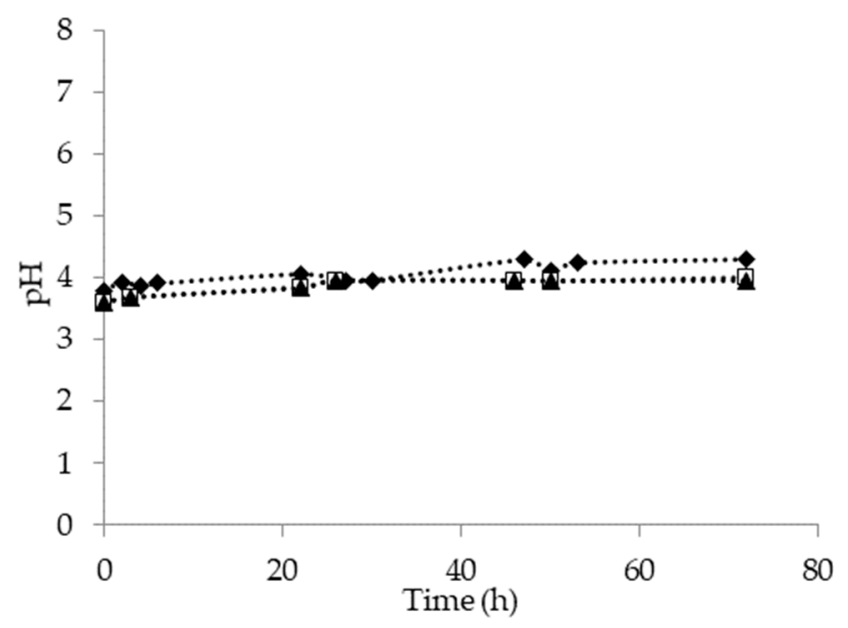

Figure 7. $\mathrm{pH}$ evolution during the aerobic biological treatment of pyrolysis wastewater at $15{ }^{\circ} \mathrm{C}$ (triangle), $25^{\circ} \mathrm{C}$ (square) and $30^{\circ} \mathrm{C}$ (rhomboid).

The same tests were performed under controlled $\mathrm{pH}$ condition (equal to 7 ) to evaluate a possible positive effect of neutral $\mathrm{pH}$ conditions when temperature is increasing. In the tests at $15^{\circ} \mathrm{C}$ and $25^{\circ} \mathrm{C}$ neutral $\mathrm{pH}$ condition did not affect the organic removals. The TOC removal yield was $10.24 \%$ and $19.94 \%$ respectively. Conversely, the inhibition due to neutral $\mathrm{pH}$ conditions was observed during the test performed at the higher temperature $\left(30^{\circ} \mathrm{C}\right)$ in which a substantial decrease in terms of TOC $(30.12 \%)$ and COD $(39.40 \%)$ was observed.

\subsection{Kinetic Analysis}

Figure 8 reports the observed first-order kinetic at different initial organic contents as COD.

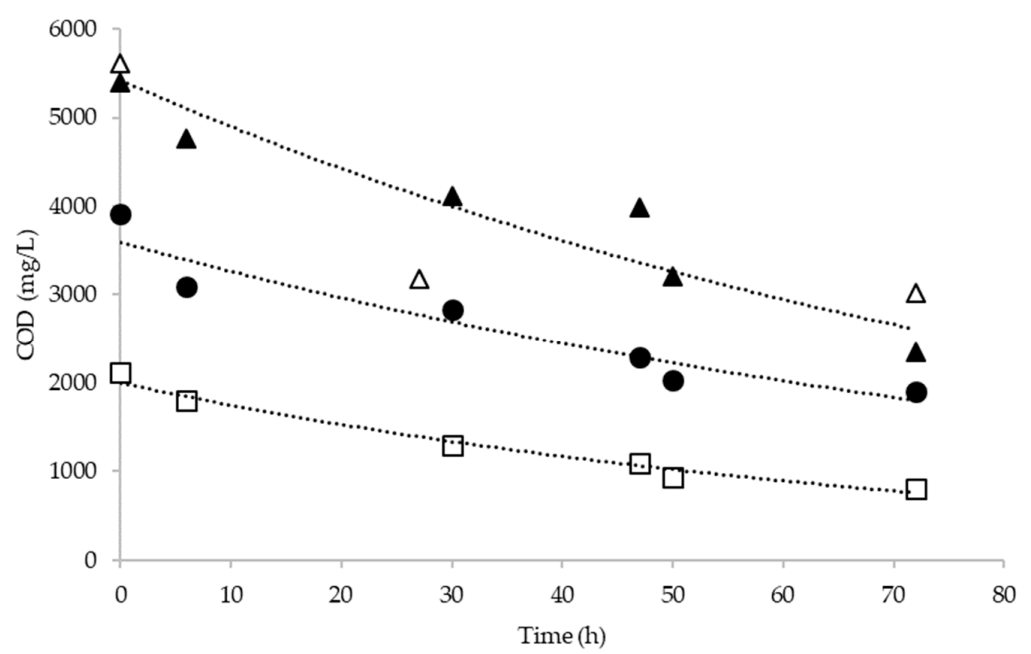

Figure 8. COD vs. time and first order kinetics at different initial concentration (TOC initial concentration: $(\bigcirc) 800 \mathrm{mg} / \mathrm{L},(\bullet) 1400 \mathrm{mg} / \mathrm{L},(\boldsymbol{\Delta}) 2000 \mathrm{mg} / \mathrm{L}$ and $(\square) 2800 \mathrm{mg} / \mathrm{L})$. 
The substrate (expressed as COD) removal rate of an enzyme-catalyzed reaction is described by Equation (1) according to the model of Michaelis Menten.

$$
\frac{\mathrm{dCOD}}{\mathrm{d} t}=-\frac{V_{\max } \times \mathrm{COD}}{K_{M}+\mathrm{COD}} \times \frac{X}{Y}
$$

where $X$ is the biomass concentration and $V_{\max }$ is the maximum reaction velocity, $Y$ is the biomass yield coefficient and $K_{M}$ is the Michaelis Menten constant showing the affinity between enzyme and substrate. In the case of a fist-order kinetic (COD concentration much lower than $K_{M}$ ), it is possible to rewrite Equation (1), and expressed as Equation (2):

$$
\frac{\mathrm{dCOD}}{\mathrm{d} t}=-\frac{V_{\max } \times \mathrm{COD}}{K_{M} Y} \times X
$$

with an apparent kinetic constant, $v_{a}=\left(V_{\max } X\right) /\left(K_{M} Y\right)$ which has been determined through data fitting with an exponential decay, as depicted in Figure 8. The resulting non-dimensional equation describing completely the experimental data-set, with an average pre-exponential factor $v_{a}=0.0121 / \mathrm{h}$, is reported in Equation (3):

$$
\frac{\operatorname{COD}(\mathrm{t})}{\mathrm{COD}_{0}}=\exp \left(-v_{a} \times t\right)
$$

The $v_{a}$ values, obtained at different $\mathrm{pH}$ values, have been fitted by a least-squares procedure and plotted against the $\mathrm{pH}$ in Figure 9.

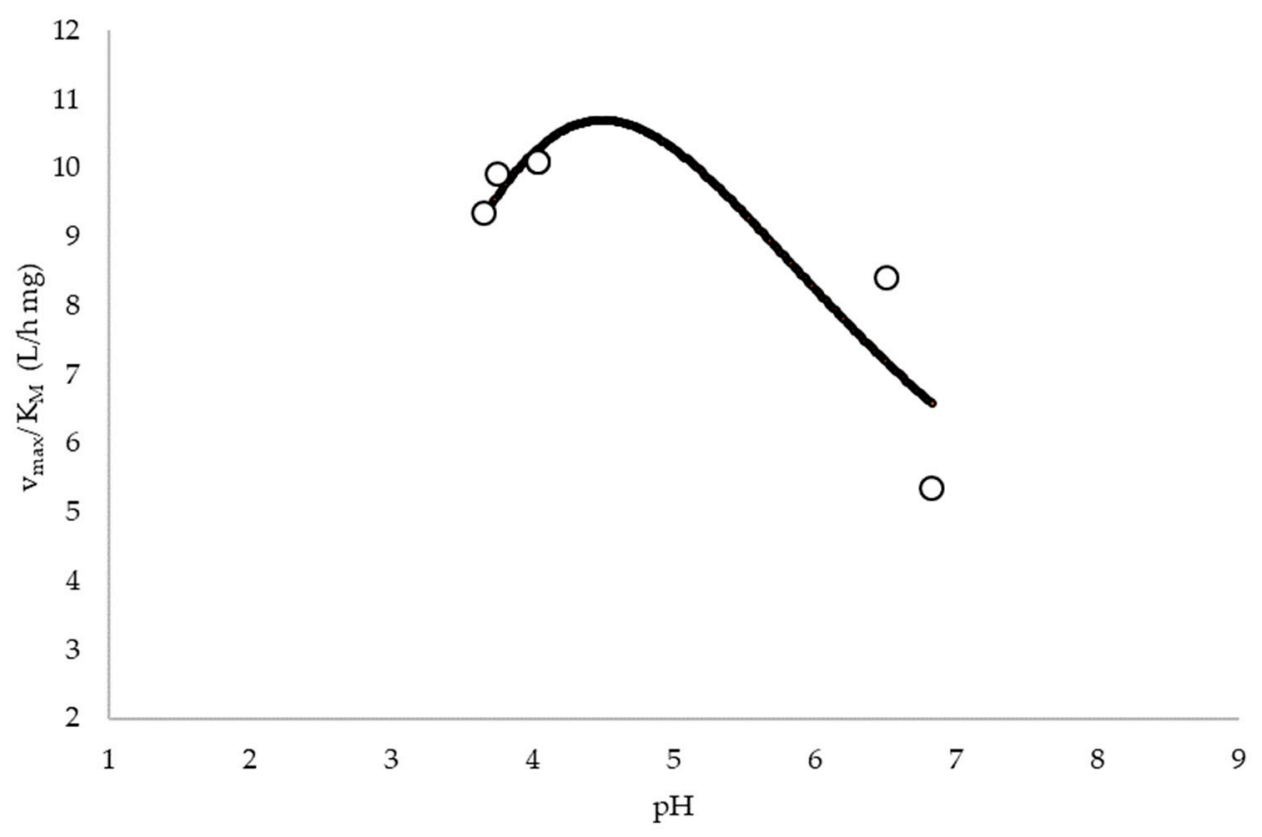

Figure 9. Effect of $\mathrm{pH}$ on the kinetics of COD degradation at $\mathrm{TOC}_{0}=1400 \mathrm{mg} / \mathrm{L}$ and $\mathrm{T}=30^{\circ} \mathrm{C}$.

The activities of many enzymes vary with $\mathrm{pH}$, according to the dissociation of acids and bases, which can modify the overall electrical distribution on active catalysis site, by modifying enzyme catalysis capacity. The plot of $\left(v_{a}\right)$ vs. $(\mathrm{pH})$ shows an optimal $\mathrm{pH}$ condition, that can be described by Equation (4)

$$
v_{e f f}=\frac{v_{a}}{1+\frac{K_{I I}}{\left[\mathrm{H}^{+}\right]}+\frac{\left[\mathrm{H}^{+}\right]}{K_{I}}}
$$

where $v_{a}$ is the fitted kinetic parameter, $v_{\text {eff }}$ is the ' $\mathrm{pH}$-corrected' parameter, $\left[\mathrm{H}^{+}\right]$is the hydrogen-ion concentration and $K_{I}$ and $K_{I I}$ are the ions dissociation constants. Similar results obtained for phenolic 
compounds in another study [26] proved the $\mathrm{pH}$-stability of enzymes and the dissociation pathways in the same optimal $\mathrm{pH}$ range of 5-6.

Finally, the temperature effect on kinetic parameters is reported as linear regression of $\left(v_{a}\right)$ vs. $(1 / T)$, as shown in Figure 10.

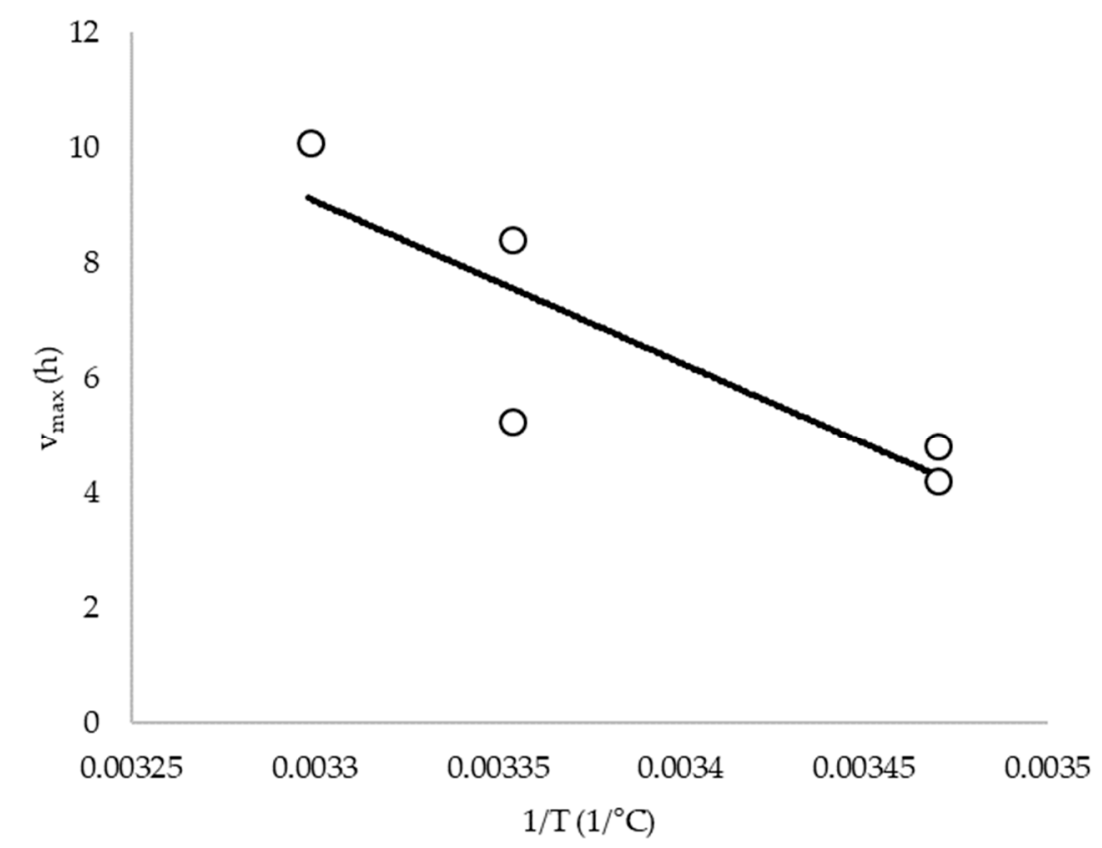

Figure 10. Effect of temperature on the kinetics of COD degradation at $\mathrm{TOC}_{0}=1400 \mathrm{mg} / \mathrm{L}$ and $\mathrm{pH}=7$.

Equation (5) that best fits the experimental data obtained at $\mathrm{pH}=7$, is:

$$
v_{a}=101.8-2.81 \times 104 / T
$$

This equation shows that a temperature increases has a positive effect on reaction velocity in the range below the beginning of thermal unfolding of enzyme structure.

\section{Conclusions}

An aerobic biological process was proposed and tested for the treatment of pyrolysis wastewater. The effect of initial TOC concentration, $\mathrm{pH}$ and temperature was investigated. Results show that a single aerobic biological process can be successfully used to induce organic mineralization. These results are promising in view of implementing a simple and cost effective method to reduce the environmental impact of pyrolysis residues, to be applied to small size plant, where byproducts recovery is not economically feasible.

The efficiency of the removal of TOC, after $72 \mathrm{~h}$ of treatment, was $55.65 \%, 49.47 \%$ and $53.03 \%$ in experiments with initial TOC of $800 \mathrm{mg} / \mathrm{L}, 1400 \mathrm{mg} / \mathrm{L}$ and $2000 \mathrm{mg} / \mathrm{L}$ respectively. The COD/TOC ratio was almost constant in all tests and a substrate inhibition on microorganism activity at high TOC initial value $(2800 \mathrm{mg} / \mathrm{L})$ was observed. An increase of removal efficiency could be successfully achieved by implementing a double step treatment. Experiments performed by adding the microbial biomass after $72 \mathrm{~h}$ showed that a TOC removal of $61.80 \%$ after $144 \mathrm{~h}$ was obtained and a reduction of COD/TOC from 2.72 to 1.77 was also observed. These results were attributed to the large amount of recalcitrant compounds compared to biological oxidation in the wastewater. A further enhancement of the overall treatment efficiency could be achieved by introducing a pretreatment of chemical oxidation, to increase the biodegradable fraction of the pollutant loading. 
Author Contributions: L.D.P., I.B., M.C., P.D.F. and V.P. conceived and designed the experiments; I.B. performed the experiments; I.B. and M.C. analyzed the data; L.D.P. and P.D.F. contributed reagents/materials/analysis tools; L.D.P., I.B., M.C., P.D.F. and V.P wrote the paper.

Conflicts of Interest: The authors declare no conflict of interest.

\section{Symbols Used}

$\begin{array}{lll}\text { COD } & (\mathrm{mg} / \mathrm{L}) & \begin{array}{l}\text { chemical oxygen demand } \\ \text { semi-saturation constant }\end{array} \\ K_{M} & (\mathrm{mg} / \mathrm{L}) & \text { temperature } \\ T & \left({ }^{\circ} \mathrm{C}\right) & \text { time } \\ T & (\mathrm{~h}) & \text { total organic carbon } \\ \text { TOC } & (\mathrm{mg} / \mathrm{L}) & \text { observed initial rate } \\ V & (1 / \mathrm{h}) & \text { apparent rate } \\ v_{a} & (1 / \mathrm{h}) & \text { effective } \mathrm{pH}-\text { corrected rate } \\ v_{\text {eff }} & (1 / \mathrm{h}) & \text { limiting value of the rate } \\ v_{\max } & (1 / \mathrm{h}) & \text { biomass concentration } \\ X & (\mathrm{mg} / \mathrm{L}) & \end{array}$

\section{References}

1. Inguanzo, M.; Domínguez, A.; Menéndez, J.A.; Blanco, C.G.; Pis, J.J. On the pyrolysis of sewage sludge: The influence of pyrolysis conditions on solid, liquid and gas fractions. J. Anal. Appl. Pyrol. 2002, 63, $209-222$. [CrossRef]

2. Agrafioti, E.; Bouras, G.; Kalderis, D.; Diamadopoulos, E. Biochar production by sewage sludge pyrolysis. J. Anal. Appl. Pyrol. 2013, 101, 72-78. [CrossRef]

3. Ioannidou, O.; Zabaniotou, A. Agricultural residues as precursors for activated carbon production-A review. Renew. Sustain. Energy Rev. 2007, 11, 1966-2005. [CrossRef]

4. Salehin, S.; Aburizaiza, A.S.; Barakat, M.A. Activated carbon from residual oil fly ash for heavy metals removal from aqueous solution. Desalin. Water Treat. 2016, 57, 278-287. [CrossRef]

5. De Filippis, P.; Di Palma, L.; Petrucci, E.; Scarsella, M.; Verdone, N. Production and characterization of adsorbent materials from sewage sludge by pyrolysis. Chem. Eng. Trans. 2013, 32, 205-210.

6. Hernández-Montoya, V.; García-Servin, J.; Bueno-López, J.I. Thermal treatments and activation procedures used in the preparation of activated carbons. In Lignocellulosic Precursors Used in the Synthesis of Activated Carbon; Intech: Rijeka, Croatia, 2012; pp. 19-36.

7. Seggiani, M.; Vitolo, S.; De Filippis, P. Effect of pre-oxidation on the porosity development in a heavy oil fly ash by $\mathrm{CO}_{2}$ activation. Fuel 2005, 84, 1593-1596. [CrossRef]

8. Guerrero, M.; Ruiz, M.P.; Alzueta, M.U.; Bilbao, R.; Millera, A. Pyrolysis of eucalyptus at different heating rates: Studies of char characterization and oxidative reactivity. J. Anal. Appl. Pyrol. 2005, 74, 307-314. [CrossRef]

9. Guillén, M.D.; Manzanos, M.J. Study of the volatile composition of an aqueous oak smoke preparation. Food Chem. 2002, 79, 283-292. [CrossRef]

10. Solantausta, Y.; Beckman, D.; Bridgwater, A.; Diebold, J.; Elliott, D. Assessment of liquefaction and pyrolysis systems. Biomass Bioenergy 1992, 2, 279-297. [CrossRef]

11. Bubonja-Sonje, M.; Giacometti, J.; Abram, M. Antioxidant and antilisterial activity of olive oil, cocoa and rosemary extract polyphenols. Food Chem. 2011, 127, 1821-1827. [CrossRef]

12. Mohan, D.; Pittman, C.U., Jr.; Steele, P.H. Pyrolysis of wood/biomass for bio-oil: A critical review. Energy Fuel 2006, 20, 848-889. [CrossRef]

13. de Caprariis, B.; De Filippis, P.; Hernandez, A.D.; Petrucci, E.; Petrullo, A.; Scarsella, M.; Turchi, M. Pyrolysis wastewater treatment by adsorption on biochars produced by poplar biomass. J. Environ. Manag. 2017, 197, 231-238. [CrossRef] [PubMed]

14. Capocelli, M.; Joyce, E.; Lancia, A.; Mason, T.J.; Musmarra, D.; Prisciandaro, M. Sonochemical degradation of estradiols: Incidence of ultrasonic frequency. Chem. Eng. J. 2012, 210, 9-17. [CrossRef]

15. Capocelli, M.; Prisciandaro, M.; Lancia, A.; Musmarra, D. Modeling of cavitation as an advanced wastewater treatment. Desalin. Water Treat. 2013, 51, 1609-1614. [CrossRef] 
16. Mehrjouei, M.; Muller, S.; Moller, D. Treatment of pyrolysis wastewater using heterogeneous advanced oxidation processes. Environ. Prog. Sustain. 2013, 33, 178-183. [CrossRef]

17. Silva, J.R.O.; Santos, D.S.; Santos, U.R.; Eguiluz, K.I.B.; Salazar-Banda, G.R.; Schneider, J.K.; Krause, L.C.; López, J.A.; Hernández-Macedo, M.L. Electrochemical and/or microbiological treatment of pyrolysis wastewater. Chemosphere 2017, 185, 145-151. [CrossRef] [PubMed]

18. Musmarra, D.; Prisciandaro, M.; Capocelli, M.; Karatza, D.; Iovino, P.; Canzano, S.; Lancia, A. Degradation of ibuprofen by hydrodynamic cavitation: Reaction pathways and effect of operational parameters. Ultrason. Sonochem. 2016, 29, 76-83. [CrossRef]

19. Liu, Z.; Xie, W.; Li, D.; Peng, Y.; Li, Z.; Liu, S. Biodegradation of phenol by bacteria strain Acinetobacter Calcoaceticus PA isolated from phenolic wastewater. Int. J. Environ. Res. Public Health 2016, 13, 300. [CrossRef]

20. Zhou, H.; Wei, C.; Zhang, F.; Liao, J.; Hu, Y.; Wu, H. Energy-saving optimization of coking wastewater treated by aerobic bio-treatment integrating two-stage activated carbon adsorption. J. Clean. Prod. 2018, 175, 467-476. [CrossRef]

21. Zhu, H.; Han, Y.; Xu, C.; Han, H.; Ma, W. Overview of the state of the art of processes and technical bottlenecks for coal gasification wastewater treatment. Sci. Total. Environ. 2018, 637-638, 1108-1126. [CrossRef]

22. APHA; AWWA; WPCF. Standard Methods for the Examinations of Water and Wastewater, 17th ed.; American Public Health Association: Washington, DC, USA, 2005.

23. Ruiz-Ordaz, N.; Hernández-Manzano, E.; Ruiz-Lagúnez, J.C.; Cristiani-Urbina, E.; Galíndez-Mayer, J. Growth kinetic model that describes the inhibitory and lytic effects of phenol on Candida tropicalis yeast. Biotechnol. Prog. 1998, 14, 966-969. [CrossRef] [PubMed]

24. Cazar, M.E.; Schmeda-Hirschmann, G.; Astudillo, L. Antimicrobial butyrolactone I derivatives from the Ecuadorian soil fungus Aspergillus terreus Thorn. var terreus. World J. Microbiol. Biotechnol. 2005, 21, 1067-1075. [CrossRef]

25. Narendranath, N.V.; Thomas, K.C.; Ingledew, W.M. Effects of acetic acid and lactic acid on the growth of Saccharomyces cerevisiae in a minimal medium. J. Ind. Microb. Biotechnol. 2001, 26, 171-177. [CrossRef]

26. Beltran, F.J.; Alvarez, P.M.; Rodriguez, E.M.; Garcia-Araya., J.F.; Rivas, J. Treatment of high strength distillery wastewater (cherry stillage) by integrated aerobic biological oxidation and ozonization. Biotechnol. Prog. 2001, 17, 462-467. [CrossRef] [PubMed]

27. Rezasoltani, S.; Shayegan, J.; Jalali, S. Effect of $\mathrm{pH}$ on aerobic granulation and treatment performance in sequencing batch reactors. Chem. Eng. Technol. 2015, 38, 851-858. [CrossRef] 